\title{
Context-Driven Entrepreneurial Education in Vocational Schools
}

\author{
Sharmila Sandirasegarane, Staci Sutermaster, Alyssa Gill, Jennifer \\ Volz, and Khanjan Mehta \\ Pennsylvania State University \\ 213U Hammond Bldg, 16802, University Park, USA
}

Received: 06.01.2016; Accepted: 03.03.2016; Published: 24.08.2016

\begin{abstract}
Vocational Education and Training (VET) is offered throughout the world to students of various educational backgrounds and career aspirations in an effort to create a skilled workforce. The structure of VET varies greatly across different fields and countries with high-growth, low-growth, and transitional economies. However, a common critique of many vocational institutions is that they focus on skills training without addressing related business systems. Thus, students may not understand the business strategies related to their field, which stifles job readiness and entrepreneurial potential. To counter this, a more context-driven and integrated entrepreneurial approach is proposed for VET. Benefits, disadvantages, and exemplars of various types of vocational and entrepreneurial programs are evaluated to determine how their strengths might be leveraged. Such integrated entrepreneurial and vocational training would more suitably address context-specific market needs via both practical and transferrable skills, thus helping to reduce unemployment, particularly among youth in sub-Saharan Africa.
\end{abstract}

Keywords: Vocational Education and Training, Entrepreneurship, VET, Youth Unemployment, Sub-Saharan Africa

\footnotetext{
${ }^{*}$ Corresponding author: asharmila383@gmail.com
}

ISSN: 2197-8646

http://www.ijrvet.net 


\section{Introduction}

Many countries face a high unemployment rate among their youth, especially youth with low qualifications (Biavaschi et al., 2012; Blanchflower and Bell, 2011; OECD and ILO, 2011; Quintini et al., 2007). In particular, low-skilled individuals face persistent, long-term effects from their early unemployment and are thus more vulnerable in the labor market throughout their lives (Scarpetta et al., 2010). As such, early education and training are strong determinants of an individual's successful transition into and existence in the workforce (Biavaschi et al., 2012).

There are many different foci for youth education. Most secondary schools focus on general academics with little emphasis on direct-application of technical skills. Vocational education training (VET) provides these practical skills, either while integrated into traditional curricula or via a separate vocational school system. However, standard VET programs do not provide practical foundations in business or entrepreneurship, which is increasingly viewed as valuable for improving livelihoods (Biavaschi et al., 2012). In fact, entrepreneurship training (ET) is considered an avenue to economic independence even in labor markets that cannot accommodate skilled graduates (Awogbenle and Iwuamadi, 2010).

Both vocational and entrepreneurial education techniques have strengths and weaknesses in delivery to students and in potential for job opportunities. This article evaluates various types of vocational and entrepreneurial educational programs, highlighting the key takeaways of the different categories of existing programs. First, the current states of VET and ET are investigated. Then, each program is reviewed for its vocational transferability and entrepreneurial potential in order to identify gaps and consider the potential for merging approaches. By considering the strengths and weakness of the said program types, an innovative model integrating both vocational and entrepreneurial approaches to applied education is proposed. The proposed model is applicable to parties working in education policy, VET or ET institutions, and general education administrators, particularly in resource-constrained settings. This approach can be applied to improve the current approach to both vocational and entrepreneurial education in resource-constrained settings, particularly in sub-Saharan Africa (SSA).

\section{Current State of Vocational Education}

Vocational education originated from a combination of historical events that shaped a need for skilled labor. Starting in the mid-1800s, industrial training with machinery started to replace the work of craftsmen, altering the style of traditional apprenticeships (Hoffman and Hoffman, 1976). Apprenticeships became less common as more formalized vocational training was established, including public vocational schools (Henry, 1943). VET programs that later arose in SSA were based on these models from former colonial powers and rapidly-industrializing countries (Atchoarena and Delluc, 2002).

Thus, the delivery of VET across SSA includes varying degrees of school-based training along with non-formal training, as illustrated in Table 1 (Atchoarena and Delluc, 2002; 
Biavaschi et al., 2012). VET programs exist at lower, upper, and post-secondary levels, but often fail to reflect the most common informal industries of an area, such as by having schools for obsolete industries and failing to update training as a field modernizes (Biavaschi et al., 2012). There are also deficits in instructional tools for VET; in Nigeria for example, the national expenditure on education is less than $26 \%$ of the UNESCO recommendations (Ejili, 2014). A related problem is inadequate oversight to ensure that the programs are regularly accredited and standards are met (Ejili, 2014).

Different types of VET programs in SSA have widely disparate effects on students. For instance, the general education vocational programs offered in countries including Botswana, Ghana, and Kenya usually meet five class periods per week and cover broad subjects such as agriculture, crafts, and domestic science. While they are more expensive than general academic classes due to their resource requirements, studies have yielded no correlation to student advantage in the labor market (Lauglo et al., 2003).

Mozambique instead runs a dual vocational education and training program as a culmination of elementary and secondary-school VET programs. After completing fifth class (grade), students spend three years in limited practical training for a profession and then another three years in more advanced theoretical and practical training. Alternatively, students from tenth class can enter into four year, technician-level training programs in fields including agriculture. While the programs are intensive, there have been problems including a lack of funding, poor infrastructure, improper teaching, and outdated curricula. These issues exist despite some successful reforms since 1998 that have introduced more practical training and subject changes, including the addition of computing and management (Atchoarena and Delluc, 2002).

Above the secondary level is the school-based vocational education model. In this example, the University of Botswana offers technician training in fields such as engineering, including specific job-tailored courses by the Roads Department and the Ministry of Health. Pre-service, in-service, and on-the-job training are also offered for the various vocational courses, which last from a few weeks to four years. However, the University of Botswana and many others lack adequate training facilities and generally have 100 applicants for each spot in an institution. There are limited opportunities for training, and even these positions may not meet the dynamic nature of the industries covered due to technological advancements (Atchoarena and Delluc, 2002).

Apprenticeships either occur through informal understandings between workplaces and prospective workers or through formal programs. Most informal programs are based on reputation, with training rules related mostly to social agreements (International Labor Organization, 2014). Labor markets in SSA are highly informal and feature many traditional apprenticeships particularly in craft sectors (Biavaschi et al., 2012). In Tanzania, the Vocational Education Training Authority (VETA) recognizes that an informal apprenticeship is a useful way for thousands of youth to gain skills in various trades, especially when they do not further their education past secondary school. In order to improve informal apprenticeships, VETA is collaborating with informal and formal enterprises to administer an initial learning assessment followed by a certification in fields ranging from carpentry to motor vehicle mechanics to food production. While these steps help make apprenticeships more structured and better regulated, there are 
still general problems with working conditions, wages, and gender imbalances (Makene, 2014).

More formal independent vocational institutions are privately organized either in country or by international organizations. For instance, Ajuda de Desenvolvimento de Povo para Povo (ADPP) is a nonprofit organization based in Mozambique that has vocational institutions in three different cities. Targeting youth as young as thirteen years, training areas include agriculture and livestock, business management, civil construction, hospitality and tourism, and community instruction. While business management training is provided as its own track, there is no explicit business training within the other tracks. Each program lasts two years, including both theoretical and practical training as well as internship experience. The vocational schools were established in 1984, and a total of 5,400 students have graduated as of 2013 .

Despite its diversity, VET faces a general lack of acceptance among employers and young people in most SSA countries (Biavaschi et al., 2012). This social norm exists largely because of stigma stemming from previous handling of VET programs in the region. For instance, quality VET institutions suffered heavily under the public spending cuts that resulted from the economic difficulties in SSA during the 1980s. The reform processes of the 1990s granted more autonomy to VET institutions, promoting private providers and addressing access for the poor, but recommended policy shifts have resulted in little widespread action (Caddell and Holmes, 2003).

Governments still play a crucial role in enhancing constituents' skill development, but they continuously struggle to gain necessary private or independent funding and collaboration (Atchoarena and Esquieu, 2002). These norms can hinder high levels of productivity and innovation in their respective economies. There have also been independent efforts to modernize and popularize vocational training, but these small programs often operate only in the pilot phase and are thus tied to traditional sectors with little mobility or entrepreneurial insight (Biavaschi et al., 2012).

\section{Current State of Entrepreneurship Education}

An entrepreneurial mind-set adds value across business, social, government, and academic sectors by promoting innovative problem identification and value creation (Gedeon, 2012; Chankseliani and Relly, 2016). Applying various entrepreneurial skills has led directly to observable improvement in work quality and productivity in a range of fields (van Praag and Versloot, 2007). Furthermore, the correlation between entrepreneurship education and entrepreneurial intentions are well-documented, including in a study of over five hundred VET trainees in Tanzania (Olomi and Sinyamule, 2009; Rambe et al., 2015). To combat youth unemployment in SSA, entrepreneurial training (ET) is being utilized to tap into a network of self-starting motivated students.

ET has the power to reduce poverty and create growth in Africa by increasing youths' human capital and accelerating long-term professional growth (Awogbenle, 2010). Entrepreneurial skills enable productive self-employment, help achieve economic stability, and can also reduce delinquent activity. These results can revitalize local communi- 
Table 1: General VET types in various sectors with typical benefits and disadvantages (adapted from Biasvaschi, et al., 2012)

\begin{tabular}{|c|c|c|c|}
\hline Type & Description & Advantages & Disadvantages \\
\hline $\begin{array}{l}\text { General Educa- } \\
\text { tion }\end{array}$ & $\begin{array}{l}\text { School-based aca- } \\
\text { demic education } \\
\text { at secondary and } \\
\text { tertiary levels }\end{array}$ & $\begin{array}{l}\text { Considered a } \\
\text { channel to ac- } \\
\text { cess high-paying } \\
\text { jobs; broadly } \\
\text { applicable }\end{array}$ & $\begin{array}{l}\text { Indirectly appli- } \\
\text { cable; may have } \\
\text { weak links to } \\
\text { market demands; } \\
\text { long duration; } \\
\text { high cost }\end{array}$ \\
\hline $\begin{array}{lr}\text { Dual } & \text { Voca- } \\
\text { tional } & \text { Edu- } \\
\text { cation } & \text { and } \\
\text { Training } & \end{array}$ & $\begin{array}{l}\text { Workplace expe- } \\
\text { rience and train- } \\
\text { ing partnered } \\
\text { with school-based } \\
\text { education in } \\
\text { specific sector }\end{array}$ & $\begin{array}{l}\text { General skills } \\
\text { are transferrable } \\
\text { across employers; } \\
\text { smooth transition } \\
\text { between school } \\
\text { and work }\end{array}$ & $\begin{array}{l}\text { Requires signifi- } \\
\text { cant public and } \\
\text { private institu- } \\
\text { tional support }\end{array}$ \\
\hline $\begin{array}{l}\text { School-based } \\
\text { Vocational } \\
\text { Education }\end{array}$ & $\begin{array}{l}\text { Specialized } \\
\text { tracks above } \\
\text { secondary level; } \\
\text { more occupation- } \\
\text { specific than } \\
\text { academically } \\
\text { focused }\end{array}$ & $\begin{array}{l}\text { Requires less time } \\
\text { and capital than } \\
\text { general educa- } \\
\text { tion; attempts } \\
\text { direct entry into } \\
\text { labor market }\end{array}$ & $\begin{array}{l}\text { Requires close } \\
\text { partnership } \\
\text { between em- } \\
\text { ployers, unions, } \\
\text { and educational } \\
\text { institutions }\end{array}$ \\
\hline Apprenticeship & $\begin{array}{l}\text { Method of learn- } \\
\text { ing job-related } \\
\text { skills during } \\
\text { employment, } \\
\text { may include a } \\
\text { certificate }\end{array}$ & $\begin{array}{l}\text { Better pay in } \\
\text { short-run com- } \\
\text { pared to com- } \\
\text { pleting training } \\
\text { programs before } \\
\text { work, addresses } \\
\text { needs of cur- } \\
\text { rent employers } \\
\text { directly }\end{array}$ & $\begin{array}{l}\text { Lack of training } \\
\text { in general occu- } \\
\text { pational skills de- } \\
\text { creases employa- } \\
\text { bility and adapt- } \\
\text { ability for other } \\
\text { jobs }\end{array}$ \\
\hline $\begin{array}{l}\text { Independent } \\
\text { Vocational } \\
\text { Institutions }\end{array}$ & $\begin{array}{l}\text { Private institu- } \\
\text { tions for specific } \\
\text { sectors; may } \\
\text { have government } \\
\text { subsidies or tax } \\
\text { incentives }\end{array}$ & $\begin{array}{l}\text { Can target both } \\
\text { high- and low- } \\
\text { income groups }\end{array}$ & $\begin{array}{lr}\text { Rely on tuition } \\
\text { revenue; } & \text { quality } \\
\text { not well regu- } & \text { rated and } \\
\text { laries } \\
\text { depending } & \text { on } \\
\text { institution } & \end{array}$ \\
\hline
\end{tabular}


ties with young professionals seeking new economic opportunity and providing broadly transferable skills, diversified livelihoods, and better financial security (Caddell et al., 2003).

Current ET programs are categorized by level of education and integration, each with varying advantages and disadvantages (Table 2). The first is general education, which lacks emphasis on entrepreneurial topics. Dual entrepreneurial education and training involves workplace experience through ET alongside simultaneous general education. In Botswana, Uganda, and Kenya, mandatory secondary school learning objectives include developing entrepreneurial attitudes and building skills in starting and managing a business (Farstad, 2002). This dual program can also include periods of work placement and the preparation of business plans.

School-based entrepreneurial initiatives, which incorporate varying levels of ET through courses, partnerships, and events, are also becoming common in SSA secondary schools. Entrepreneurial education has been offered at both junior and senior secondary general education levels in some schools in Botswana, Kenya, and Uganda. These programs include courses on business studies or career guidance, which meet three class periods per week. In both Botswana and Kenya, general secondary schools may also partner with a Junior Achievement Foundation, where students participate in a year long, supplemental Company Program, which functions as an extracurricular activity. Although students are exposed to entrepreneurship at a young age, most knowledge is very general and does not directly affect business potential after program graduation (Farstad, 2002). Some ET programs also exist at advanced levels, including most universities and technical institutes in South Africa, which typically offer more relevant entrepreneurial centers or diplomas in small business (Nieman, 2001).

In contrast, apprenticeship opportunities use an applied on-the-job learning process by enabling students to work and learn with other entrepreneurs. South African youth can gain entrepreneurial skills by joining the Youth Enterprise Society (YES). Members are a part of a team that meets weekly to actively compete against other teams by improving real business start-ups and increasing profits. Students work directly with local partners, including business people, community leaders, government officials, and educators, all facilitated by a larger organization, the Education with Enterprise Trust. However, it is a challenge to determine which aspects of apprenticeship ET correlate to start-up success post-training (North, 2002). For instance, apprenticeship-only programs may not provide the flexible skills and knowledge needed to help alumni find other niches and design new products (Afenyadu et al., 2001). They can also produce gluts of apprentices in low-demand fields, or an exclusion of apprentices from promising fields that lack current entrepreneurial mentors.

The final type of ET is independent entrepreneurial training, which is business development education delivered by freestanding institutions dedicated to providing training for specific professions. These programs can be funded by government agencies, NGOs, or community-based organizations. Independent entrepreneurial institutions are common in South Africa, but a large majority still lack properly trained teachers and strong networking opportunities (Nieman, 2001). 
There are certain exceptions, such as Junior Achievement Southern Africa, which has partnered productively with a university business center and multiple private and foreign investors (North, 2002). Such business centers can provide financial support, counseling, and business planning in addition to high-quality training (Nieman, 2001). The government-run Business Advisory Service in Gambia is another strong example; it provides expert advice to skilled technical workers who are potential entrepreneurs (Fredrick, 1998). Finally, budding entrepreneurs in Kenya, Tanzania, and Uganda can use the freestanding Improve Your Business entrepreneurial program to access materials-based training, network with financial institutions, and start savings and lending clubs. This type of ET program is very beneficial for new entrepreneurs and promoting entrepreneurship in general, and is one of several that could be integrated with VET. The varying ET programs are summarized in Table 2 with their advantages and disadvantages highlighted.

When a standard entrepreneurial curriculum in South Africa was established 2005, the government determined that in order to truly improve economic growth, entrepreneurship education should be incorporated into every educational level (North, 2002). This model has functioned successfully in Botswana's primary, junior secondary, and senior secondary schools, with many students crediting their motivation and confidence for seeking self-employment to integrated ET (Farstad, 2002). Regardless of type or location, such successful ET programs have incorporated business plan development, partnerships between business centers and student-operated enterprises, and required periods of work during schooling.

It is thus essential that organizations, such as training facilities partnered with private enterprises, collaborate together on curriculum and instruction format. However, inertia, resource constraints, and innovation limitations have stifled the implementation of these ET policy shifts (Isaacs et al., 2007). There are thus significant opportunities to improve ET and incorporate VET programs in countries including Ghana, South Africa, and Kenya. Such opportunities are particularly true at higher levels of education, where teacher qualifications and attitudes have been questioned (Farstad, 2002).

As with VET, there is some stigma related to being an entrepreneur in SSA. In countries including Tanzania, being an entrepreneur is associated with lower economic classes (Weiss, 2015). Also, women who self-identify as entrepreneurs may be disadvantaged, compared to men. While dependent on context, these sociocultural considerations should be evaluated when implementing ET initiatives.

\section{Extent of Vocational Focus and Entrepreneurial Transferability}

The different vocational and entrepreneurial education types have a range of strengths and weaknesses as previously outlined (Tables 1 and 2). These characteristics also affect their value along the axes of vocational focus and entrepreneurial transferability, respectively. Vocational focus adds value to programs by giving the technical training necessary in order to be successful in a particular trade. Strength of vocational focus 
Table 2: Types of entrepreneurial education programs with general benefits and disadvantages

\begin{tabular}{|c|c|c|c|}
\hline Type & Description & Benefits & Disadvantages \\
\hline $\begin{array}{l}\text { Dual En- } \\
\text { trepreneurial } \\
\text { Education and } \\
\text { Training }\end{array}$ & $\begin{array}{l}\text { Entrepreneurial } \\
\text { workplace experi- } \\
\text { ence and training } \\
\text { partnered with } \\
\text { school-based } \\
\text { education }\end{array}$ & $\begin{array}{l}\text { Required by } \\
\text { students } \\
\text { some countries, } \\
\text { includes prepa- } \\
\text { ration of work } \\
\text { placements and } \\
\text { business plan } \\
\text { creation }\end{array}$ & $\begin{array}{l}\text { May not be es- } \\
\text { tablished in areas } \\
\text { where mandates } \\
\text { exist; quality } \\
\text { of programs } \\
\text { dependent on } \\
\text { funding }\end{array}$ \\
\hline $\begin{array}{l}\text { School- } \\
\text { based En- } \\
\text { trepreneurial } \\
\text { Education }\end{array}$ & $\begin{array}{l}\text { Specialization } \\
\text { track in general } \\
\text { education, of- } \\
\text { fering varying } \\
\text { business-related } \\
\text { courses or activi- } \\
\text { ties }\end{array}$ & $\begin{array}{l}\text { Motivates and } \\
\text { builds confi- } \\
\text { dence for self- } \\
\text { employment, not } \\
\text { time intensive }\end{array}$ & $\begin{array}{l}\text { Can be challeng- } \\
\text { ing to change } \\
\text { current education } \\
\text { policy; teach- } \\
\text { ers may not be } \\
\text { qualified to teach } \\
\text { ET }\end{array}$ \\
\hline Apprenticeship & $\begin{array}{l}\text { Method of learn- } \\
\text { ing business } \\
\text { skills during en- } \\
\text { trepreneurial/enter } \\
\text { employment }\end{array}$ & $\begin{array}{l}\text { Practical learning } \\
\text { experience; im- } \\
\text { mediate income } \\
\text { prise }\end{array}$ & $\begin{array}{l}\text { Challenging to } \\
\text { find suitable } \\
\text { enterprises; mar- } \\
\text { ket demand can } \\
\text { hinder quality; } \\
\text { specificity can } \\
\text { hinder adaptabil- } \\
\text { ity }\end{array}$ \\
\hline $\begin{array}{l}\text { Independent } \\
\text { En- } \\
\text { trepreneurial } \\
\text { Institutions }\end{array}$ & $\begin{array}{l}\text { Private insti- } \\
\text { tutions, may } \\
\text { have government } \\
\text { subsidies or tax } \\
\text { incentives }\end{array}$ & $\begin{array}{l}\text { Strongly } \\
\text { entrepreneurship- } \\
\text { centered; access } \\
\text { to focused skills } \\
\text { and networking }\end{array}$ & $\begin{array}{l}\text { Unstandardized } \\
\text { curricula, may } \\
\text { lack technical } \\
\text { training and eco- } \\
\text { nomic integration }\end{array}$ \\
\hline
\end{tabular}


is determined based on the amount of time devoted to vocational training, including theoretical learning and practical experience. The authors define entrepreneurial transferability as the training's adaptability to operations across various economic sectors.

When students are equipped with adaptable entrepreneurial skills, they are more capable of creating value in their trade. Based on the differences discussed above, Figure 1 categorizes VET and ET education types by their extent of vocational focus and entrepreneurial transferability. VET apprenticeship has a high vocational focus, like most of the other VET educational types, but it can vary from having low to high entrepreneurial transferability based on the emphasis of the instructor.

Dual VET has a variable vocational focus because of potential time and funding constraints with integrating vocational training with public education. Of ET education types, dual ET has a low vocational focus and school-based ET tends to have an intermediate vocational focus, while both have intermediate entrepreneurial transferability, depending on the program. The lower left quadrant represents education with no vocational or entrepreneurial training, as is common in general education. The education types in the upper left and lower right quadrants focus only on VET or ET, respectively. The upper right quadrant designates a dual VET-ET education, which is proposed as an essential approach in this paper.

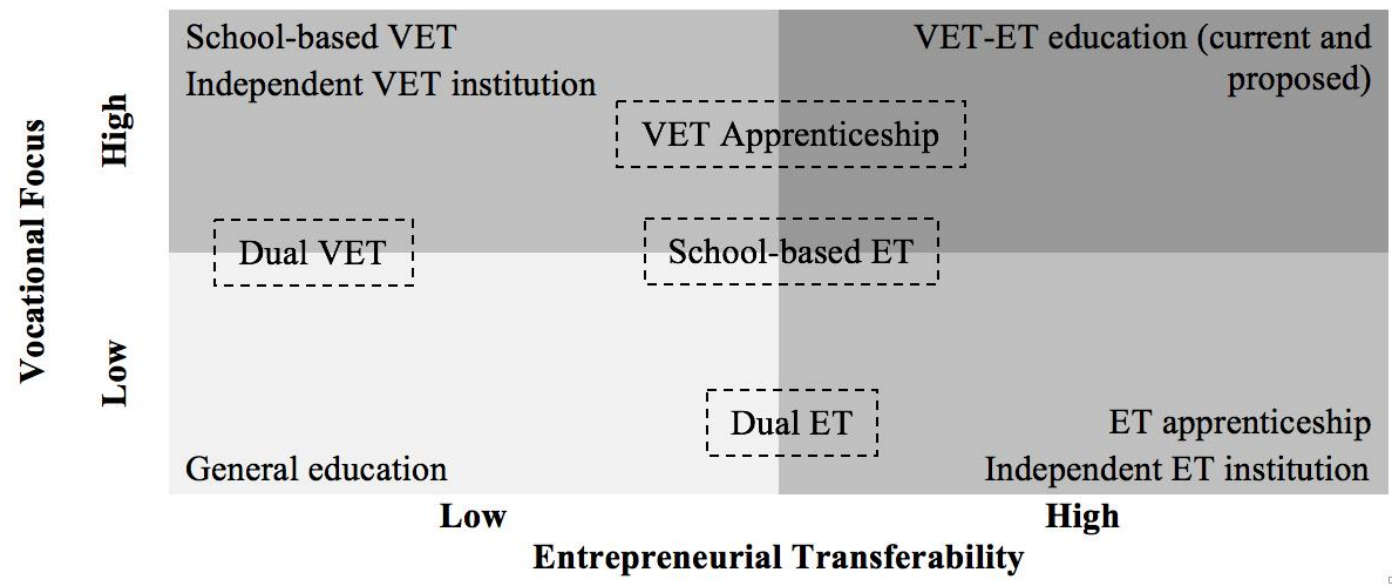

Figure 1: Degree of vocational focus and entrepreneurial transferability for VET and ET types

As mentioned, general education typically excludes entrepreneurial topics, but Botswana, Ghana, and Kenya do offer vocational classes in the general education curriculum (Lauglo et al., 2003). These programs are primarily classroom-based, limiting their applied learning opportunities, such as a practicing a skill in a workplace setting. General education programs are typically underfunded, and thus the education may not be current or context-specific. Despite funding constraints, dual VET programs in secondary schools can have a heightened emphasis on real workplace experience. This quality improves 
vocational focus, though programs still split their time with general studies (Atchoarena and Delluc, 2002). In contrast, school-based vocational education provides individualized and exclusive vocational training above the secondary level (Atchoarena and Delluc, 2002), as with the University of Botswana's engineering training.

Apprenticeships tend to place students under the direct guidance of a craftsperson or tradesperson. There is a very heavy focus on skills-based training, but there may also be an entrepreneurial emphasis depending on the mentor. This emphasis varies drastically at the individual level, though much can be learned through observation even if trainers do not concentrate on transferable entrepreneurial insights. For example, when learning about welding, the student may observe the mentor facilitating business partnerships and product promotion, providing some background into business management. Independent vocational institutions also have strong vocational foci in various sectors, but limited entrepreneurial training. While the goal of both VET types is direct entry into the labor market, the lack of broader and more flexible skillsets can leave students struggling to differentiate themselves from competitors. This issue is particularly true of SSA sectors that are already well saturated in the labor market.

As for ET program types, all those outlined in Table 2 have low vocational focus and varying levels of entrepreneurial transferability. In dual ET, students gain general organizational and problem solving skills via both general education and hands-on entrepreneurship. For example, in countries including Botswana, Kenya, and Uganda, students learn about business skills in the class and practice them during periods of work placement. However, because the hands-on application is heavily limited by the project's economic sector, dual ET has only a moderate level of transferability. School-based ET programs provide the same level of transferability, this time because the education is not always applied and tends to be a general motivator rather than a practical aid.

In contrast, entrepreneurial apprenticeships are very application heavy and involve simultaneously learning and applying common business skills and frameworks. For instance, the Tourism Confederation of Tanzania has helped launch a Certified Apprenticeship Program in Hotel Operations, a two-year program that teaches vocational skills while supporting entrepreneurship. Independent ET institutions provide the highest transferability of entrepreneurial skills because their aim is strictly entrepreneurial and the training is catered directly for self-employment and/or enterprise employment.

The analysis presented here is intended to help structure and integrate VET and ET programs in ways that will be emphasize their strengths and compensate for weaknesses. Actual programs in each category vary based on their unique features and contexts, issues that must be addressed on an individual and contextual level during the merging process.

\section{Value of Merging Vocational and Entrepreneurial Education}

Several of the strengths and weaknesses of VET and ET programs are complementary to one another, and thus can be integrated to great effect. For instance, one shortcoming of most VET programs is in restricting students to developing skills only for specific 
jobs. Transferable skills such as personal finance are often overlooked, whether applied to running a small business or saving money for a family (Cheng et al., 2012). In contrast, strong ET programs provide the transferable and transformative skills that enable graduates to find opportunities for themselves. However, such programs lack VET's direct applicability, as students can graduate with low proficiency in specific marketable trades, such as carpentry or sewing. In merged programs, the complimentary strengths in VET and ET enable students to graduate with transferrable skills and directly marketable experiences.

Table 3: Complements of VET and Entrepreneurial Programs

\begin{tabular}{ll}
\hline VET & ET \\
\hline (+) Opportunities for stu- & $(-)$ Lack of technical skill edu- \\
dents to gain practical, trade- & cation \\
based skills, within school, af- & \\
ter, or as a substitute & \\
\hline (+) Depending on region, es- & $(-)$ Lack of established infras- \\
tablished programs including & $\begin{array}{l}\text { tructure across various levels } \\
\text { all levels of education }\end{array}$ \\
& $\begin{array}{l}\text { of education (including gen- } \\
\text { grams }\end{array}$ \\
\hline $\begin{array}{l}\text { (-) Problems with meeting } \\
\text { and adapting to changing }\end{array}$ & economic opportunities \\
market demand & pro- \\
\hline $\begin{array}{l}\text { (-) Skills may not be trans- } \\
\text { ferrable to different job oppor- }\end{array}$ & transferrable to \\
tunities & sectors \\
\hline $\begin{array}{l}\text { (-) Lack of social acceptance } \\
\text { in among community about }\end{array}$ & ness people well-received by \\
program validity & community \\
\hline
\end{tabular}

Characteristics of each training institution may vary by program specifics and education type. However, Table 3 highlights the complementary nature of VET and ET. Thus, appropriately balancing the distinguishing VET and ET features can produce educational initiatives that are economically savvy, socially accepted, and institutionally viable. The next best step in this balancing process is to integrate the educational techniques together, specifically by linking curricular topics within sectors (Farstad, 2002). Such attempts should focus on enhancing enterprise understanding as well as fostering practical skillsets (Isaacs et al., 2007). The challenges will be to monitor and support the stakeholders, with clear training to create standardized curricula (Nieman, 2001). 


\section{Current State of Combined Vocational and Entrepreneurial Education}

While combining vocational and entrepreneurial programs may seem unusual, there are certain institutions in SSA that already include some valuable characteristics. Rebuild Africa was founded as a nonprofit organization and has distributed over 100 scholarships to K-12 and university students in Liberia. By integrating entrepreneurial and vocational training, the organization aims to prepare the new Liberian generation to start businesses, create jobs, lead institutions, and provide goods and services. The curriculum emphasizes both entrepreneurship and vocational training through mentoring and hands-on preparation. The combination of these skills is highly transferable and practical, for specific trades, mostly in construction.

The Brigades Centers in Botswana are also strong ET-VET institutions. These centers are owned and run by their communities and provide theoretical and practical training; some even qualify as alternative apprenticeship opportunities (Farstad, 2002). Integration can begin at the student level, with the choice to add entrepreneurship into current training. In addition, students gain VET primarily through theoretical, practical, or apprenticeship-based approaches.

In Zimbabwe, the Training for Rural Economic Empowerment Program aims to provide access to new skills and technologies, develop training in literacy and numeracy, and establish avenues for young women in male-dominated trades (International Labor Organization, 2014). Industry experts provide on-the-job training and mentoring for trades including crafts, welding and metalwork, carpentry, vehicle mechanics, and solar energy. This program addresses many of the problems with traditional apprenticeships by providing business guidance and opportunities for self-employment, including improved training techniques that go beyond traditional and informal social rites (International Labor Organization, 2014). In addition, its business guidance extends beyond general education theories and encourages direct entrepreneurship. Thus this institution provides students with highly transferrable skills as well as training in specific trades.

The West African Vocational School in Guinea-Bisseau is another vocational institution with integrated components. The program offers classes in computer basics, automobile mechanics, sewing and the English language that are marketable and high demanded in the community. In addition to the emphasis on practical skills, the program provides training and support for entrepreneurship through the provision of micro-finance loans, internships and business mentoring.

Students in the Clothing, Textile, and Interior Decoration undergraduate program at the University of Agriculture Abeokuta in Nigeria are trained to be self-employed and relevant to the industry (Amubode and Goriola, 2015). They have practical training in the industry for six months, after which they are required to compose a report about how their experience can impact their job creation. The 28 students in their final year, one-third of whom intended to become self-employed, completed the Entrepreneurship Personal Assessment Scale to assess their entrepreneurial personality traits (Amubode and Goriola, 2015). The average score was in the mid-to-lower range, indicating that 
even with the preparation, there was was room for improvement with entrepreneurial preparation. Personal factors like perceived self-efficacy could have impacted the scores, potentially affecting the effectiveness of any entrepreneurial program.

The various entrepreneurial skills taught in the above programs exemplify how training can adapt to local contexts and organizations. All of these programs attempt to integrate ET and VET synergistically, placing them in the upper right quadrant of the table (Figure 1). However, the efficacy of these and other individual programs is unclear and difficult to measure. The challenge is partially due to their novelty and lack of information, but also results from the volatile nature of entrepreneurship.

There are preliminary sources that give insight into the obstacles and results of VETET in SSA. Tanzania's Vocational Education Training Authority directors, entrepreneurship instructors, final year students, and stakeholders highlighted some of the major challenges with VET-ET (Nkirina, 2010). Some of the issues with integrating ET with VET involved limited time, varying skill levels of students, financial constraints, untrained instructors, and a lack of former successful trainees. The classes were considered to be boring, which may have been impacted by a lack of adequate resources. Similar issues were raised in technical colleges in Nairobi where entrepreneurship education was being implemented (Mkala and Wanjau, 2013). A survey of 54 teachers indicated that they tended to continue traditional teaching and assessment practices, while administrators failed to provide them adequate training and entrepreneurial contacts.

In Nigeria, integrating entrepreneurial education into VET to produce self-employed graduates has been one of the objectives in the country's National Policy on Education since 2004 (Anumnu, 2013). A study of entrepreneurial skills development in 150 lastyear students from three different VET-ET colleges in Nigeria showed that there was a significant relationship between collaborating with students and networking with mentors to the capacity to translate entrepreneurial knowledge from class into the workplace (Anumnu, 2013). While these results are not generalizable to all VET-ET programs, there is value in building partnerships with other entrepreneurs and sharing ideas among students.

The Nigerian government has called for the private sector to help develop entrepreneurial education in secondary schools, but in a study of the Kwara State, there were significant gaps in this assistance (Ogundele et al., 2013). Based on a survey of 1200 school administrators and student leaders, there was the provision of equipment from banks, politicians, and philanthropists, but little or no education for teachers or mentorship for students. While Nigeria is ahead in terms of VET-ET education, other educational programs in SSA can look to the successes and weaknesses of its system to create comprehensive curricula.

Entrepreneurship is more than business training, and even with practical start-up experience success is highly contingent on the background, character, local economy, and luck. Such ET-VET programs must thus constantly improve and adapt in order to provide their students with the strongest possible tools for success, both in their practical performance skills and ability to market those skills. Integrated ET-VET programs not only develop skills in practical trades, but they empower individuals to engage an entrepreneurial mind-set and expand their business potential. 


\section{Discussion}

Entrepreneurship is about opportunity recognition and action, while vocational education involves specific proficiency in a marketable trade. Combining aspects of both types of training allows individuals to recognize opportunities in their communities and capitalize on both skillsets to create socio-economic value and generate income. Furthermore, intersecting characteristics can help improve many ET and/or VET programs. As shown in Table 3, corresponding benefits and disadvantages of each of the approaches demonstrate how a combined method helps either VET cover the weaknesses of ET or vice versa. For example, VET may not prepare students for changing market demands while ET encourages the creation of new economic opportunities.

For both vocational and entrepreneurial education types, general education avenues ought to incorporate more practical knowledge and market exposure for students. Similarly, dual VET or ET programs should diversify or partner with each other in order to acquaint students with marketable skills and entrepreneurial attitudes, including practical activities like the creation of business plans (Farstad, 2002). For schoolbased education, post-secondary technical institutes need to address specific industry needs via robust partnerships (Atchoarena and Delluc, 2002). These deficits can be handled through supplemental entrepreneurial curricula, as with the Junior Achievement Foundation's Company Program, which gives students entrepreneurial exposure. Community-run programs, like Brigades Centers in Botswana, can also be leveraged to access entrepreneurship for community-specific trades (Farstad, 2002).

Apprenticeships can be integrated in school-based education as an extracurricular activity as with YES in South Africa. Such combinations can enhance the structure of ET programs while building social acceptance for alternative education (Makene, 2014). In fact, youth entrepreneurship competitions like YES ought to be integrated among current apprentices across various sectors.

Independent vocational and entrepreneurial institutions can offer many of the above educational adaptations. These institutions are well established in diverse fields, from agriculture to car mechanics, providing great opportunity to expand integrative education in different sectors. Another option is for existing programs to collaborate, both with each other and with local organizations. For example, Improve Your Business enables entrepreneurs to partner with financial institutions and form savings and lending clubs, but could also add more technically focused partners for support. The Business Advisory Service in Gambia offers expert advice to technical workers (Fredrick, 1998), but could also leverage existing vocational programs at neighboring institutions.

Despite the potential for vocational and entrepreneurial education to merge, programs must be thoughtfully executed to promote entrepreneurial intentions in students. Based on entrepreneurial intentions questionnaires administered to over one hundred VET students in Ethiopia, the factors that most highly impacted an entrepreneurial mind-set included personal attitudes toward the behavior and perceived behavioral control (Buli and Yesuf, 2015). Therefore, VET-ET curricula must be appropriately curated to include information that addresses these barriers, encouraging students to think creatively and use resources effectively (Buli and Yesuf, 2015). Also, a proper entrepreneurial education 
does not translate into a smooth venture creation process (Rambe et al., 2015). Students must be made aware of the challenges riddled in entrepreneurship in a practical manner, while not being discouraged by the potential failures.

A compulsory entrepreneurial education may in fact negatively correlate to entrepreneurial intentions (Oosterbeek, 2010; Fayolle, 2015). The compulsory entrepreneurial education for first and final year students at Chinhoyi University of Technology in Zimbabwe was not shown to increase entrepreneurial intentions among students (Rambe et al., 2015). Finding a way to combine integrate entrepreneurship in a non-mandatory way could be to teach VET in a way that promotes technological creativity (Rambe et al., 2015).

In accommodating programs, students could be given information about new venture creation within their VET, with more detailed instruction offered if desired. Students who feel motivated to engage in entrepreneurial activities from the exposure given could learn the ways to reach those goals, while disinterested students could pursue their work with the VET education given. However, at further education and training colleges in South Africa, entrepreneurship education was positively correlated to entrepreneurial intent (Malindi, 2014). The conflicting literature could be affected by a range of factors, including the type of program in which the mandatory entrepreneurial education is offered. Therefore, the extent of entrepreneurial integration should be decided after evaluation of issues like student preference and institutional offerings.

To address the ET-VET challenges, all stakeholders must understand the importance of the programs to the overall value chain in their sector and larger economy. This broader understanding combined with a willingness to adapt could help catalyze more systemic changes SSA, particularly as the population becomes more financially secure and innovatively engaged. Having an effectively managed VET-ET program requires the active engagement of partners and interest groups to provide adequate experience and mentorship (Buli and Yesuf, 2015). Hands-on training, which recreates real-life situations through case studies and field trips, is key to understanding how to overcome the challenges in entrepreneurship (Anumnu, 2013). Issues like government funding and accreditation that already need to be addressed for VET and ET need to be improved to provide a standard quality of education. Offering students practical skills with an entrepreneurial background has the potential to drive this forward, setting in motion both micro- and macro-scale advances in SSA socioeconomics.

\section{Conclusion}

Offering dual vocational and entrepreneurial educations will help youth build transferable competencies in entrepreneurship while fostering highly marketable skills. Together, VET and ET programs can bolster youth employability as well as enterprising behavior in local economies (Onstenk, 2003). ET and VET programs can be integrated in a number of ways to achieve this goal, depending on the strengths and weaknesses of respective program types. For instance, while not all students may be interested in entrepreneurship, exposure to the entrepreneurial skills can provide transformative understanding 
of market niches and holistic business systems. Making both of these paradigms more available to youth in sub-Saharan Africa will help empower local communities to improve their economic independence, sustainability, diversity, and productivity by expanding social welfare, and creating new jobs and markets. 


\section{References}

ADPP Mozambique (2015). Vocational Training Passport to the World of Work. Retrieved April 24, 2015, from ADPP Mozambique: http://www.adpp-mozambi que.org/education/vocational-education.

Afenyadu, D., King, K., McGrath, S., Oketch, H., Rogerson, C., \& Visser, K. (2001). Learningto Compete: Education, Training \& Enterprise in Ghana, Kenya \& South Africa. Education Research. Institute of Education Sciences, Department for International Development, London.

Amubode, A.A., \& Goriola, O.R. (2015). Assessment of entrepreneurial traits among undergraduate students of clothing, textile and interior decoration. International Journal of Marketing Studies, 7(4), 94-104.

Anumnu, S.I. (2013). Knowledge management and development of entrepreneurial skills among students in vocational technical institutions in Nigeria. Kidmore End: Academic Conferences International Limited, 37-XI.

Atchoarena, D., \& Delluc, A. (2002). Revisiting technical and vocational education in sub-Saharan Africa: An update on trends, innovations and challenges. Paris: UNESCO International Institute for Educational Planning.

Atchoarena, D., \& Esquieu, P. (2002). Private technical and vocational education in sub-Saharan Africa: Provision patterns and policy issues. Paris: UNESCO International Institute for Educational Planning.

Awogbenle, A.C. (2010). Youth unemployment: Entrepreneurship development. African Journal of Business Management, 4(6), 831-835.

Awogbenle, A. C., \& Iwuamadi, K. C. (2010). Youth unemployment: Entrepreneurship development programme as an intervention mechanism. African Journal of Business Management.

Biavaschi, C., Eichhorst, W., Giulietti, C., Kendzia, M.J., Muravyev, A., Pieters, J., Rodrguez-Planas, N., Schmidl, R., \& Zimmermann, K.F. (2012). Youth unemployment and vocational training. Bonn: Germany.

Blanchflower, D.G., \& Bell, D. N. (2011). Youth Unemployent in Europe and the United States. IZA Journal of Labor Economics.

Buli, B.M., \& Yesuf, W.M. (2015). Determinants of entrepreneurial intentions: Technical-vocational education and training students in Ethiopia. Education \& Training, 57(8/9), 891-907.

Caddell, M., \& Holmes, K. (2003). Assessing the Synthesis Report: The Response of the Working Group. Working Group for International Cooperation in Skills Development. Edinburgh: International Labour Organization.

Caddell, M., Holmes, K., Atchoarena, D., Grierson, J., \& Farstad, H. (2003). World Bank Study on: Vocational Skills Development in Sub-Saharan Africa - a Working Group Review. Edinburgh: Working Group for International Cooperation in Skills Development. 
Chankseliani, M., \& Relly, S.J. (2016). Three-Capital Approach to the Study of Young People who Excel in Vocational Occupations: A Case of WorldSkills Competitors and Entrepreneurship. International Journal for Research in Vocational Education and Training (IJRVET), 3(1), 46-65.

Cheng, A., Sinha, A., Shen, J., Mouakkad, S., Joseph, L., \& Mehta, K. (2012). Opportunities for Social Innovation at the Intersection of ICT Education and Rural Supply Chains. Global Humanitarian Technology Conference.

Ejili, A.E. (2014). Quality assurance in vocational and technical education: A panacea to youth unemployment in Nigeria. International Journal of Arts \& Sciences, $7(3), 431-445$.

Farstad, H. (2002). Integrated Entrepreneurship Education in Botswana, Uganda and Kenya. World Bank. Oslo: National Institue of Technology.

Fayolle, A. (2015). The impact of entrepreneurship education on entrepreneurial attitudes and intention: Hysteresis and persistence. Journal of Small Business Management, 53(1), 75-93.

Fredrick, M.N. (1998). Entrepreneurial skills development programs for unemployed youth in Africa: A second look. Journal of Small Business Management, 36(1), 100-103.

Gedeon, S. (2012). What is Entrepreneurship? Entreprenuerial practice review, 1(3).

Henry, N.B. (1943). Vocational Education. Chicago, IL: Department of Education, The University of Chicago.

Hoffman , A.M., \& Hoffman, D.B. (1976). History of Vocational Eduation. Buffalo, NY: State University of New York.

International Labor Organization. (2014). Improvements in Informal Apprenticeship. Retrieved April 24, 2015, from Skills for Youth: Employment and Rural Development: http://www.africayouthskills.org/Improvements_in_Informal_Appre nticeship_.

International Labour Organization. (2015). Retrieved April 26, 2015, from Apprenticeship programme-Tanzania: New apprenticeship training programme in the hospitality industry: http://www.ilo.org/addisababa/media-centre/pr/ WCMS_305607/lang-enindex.htm.

Isaacs, E., Visser, K., Friedrich, C., \& Brijlal, P. (2007). Entrepreneurship education and training at the Further Education and Training (FET) level in South Africa. South African Journal of Education, 27, 613-629.

Lauglo, J., Akyeampong, A. K., Mwiria, K., \& Weeks, S.G. (2003). Vocationalized Secondary Education Revisited, with Case Studies from Botswana, Ghana and Kenya. Working Group for International Cooperation in Skills Development. Edinburgh: International Labour Organization.

Makene, P. (2014). Apprenticeship system in informal economy vital for poor, marginalised communities. IPP Media.

Malindi, M.M. (2014). Impact of entrepreneurship education on entrepreneurial intent at further education and training (FET) colleges in South Africa. University of Pretoria: ProQuest Dissertations Publishing. 
Mkala, D.M., \& Wanjau, K. (2013). Transforming implementation of entrepreneurship education programme in technical training institutions in Kenya. European Centre for Research Training and Development UK, 1(3), 18-27.

Nieman, G. (2001). Training entrepreneurs and small business enterprises in South Africa: a situational analysis. Education \& Training, 43(8/9), 445.

Nkirina, S.P. (2010). The challenges of integrating entrepreneurship education in the vocational training system : An insight from Tanzania's Vocational Education Training Authority. Journal of European Industrial Training, 34(2), 153-166.

North, E. (2002). A decade of entrepreneurship education in South Africa. South African Journal of Education, 22(1).

OECD, \& ILO. (2011). Giving youth a better start, A policy note for the G20 Meeting of Labour and Employment Ministers, Paris.

Ogundele, M.O., Kayode, D.J., Oduleke, F.L., \& Alade, O.S. (2013). Private sectors involvement and entrepreneurial education of secondary schools in Kwara State, Nigeria. Journal of Entrepreneurship and Management, 2(1), 13-19.

Olomi, D.R., \& Sinyamule, R.S. (2009). Entrepreneurial inclinations of vocational education students: A comparative study of male and female trainees in Iringa Region, Tanzania. Journal of Enterprising Culture, 17(1).

Onstenk, J. (2003). Entrepreneurship and vocational education. European Educational Research Journal, 2(1), 74-89.

Oosterbeek, H.v. (2010). The impact of entrepreneurship education on entrepreneurship skills and motivation. European Economic Review, 54(3), 442-454.

Quintini, G., Martin, J. P., \& Martin, S. (2007). The Changing Nature of the Schoolto-Work Transition Process in OECD Countries. The WDA-HSG.

Rambe, P., Ndofirepi, T.M., \& Dzansi, D.Y. (2015). Influence of entrepreneurial education and technological creativity on entrepreneurial intentions of students in Zimbabwe: A theoretical perspective. European Conference on Innovation and Entrepreneurship, 576-584.

Ray, D.M. (1988). The role of entrepreneurship in economic development. Journal of Development Planning, 18, 3-18.

Rebuild Africa (2015). Retrieved April 26, 2015, from Our Story: http://www.rebuild africa.org/our-story/rebuild-africa.

Scarpetta, S., Sonnet, A., \& Manfredi, T. (2010). Rising Youth Unemployment During The Crisis: How to Prevent Negative Long-term Consequences on a Generation? Paris: OECD.

van Praag, C.M., \& Versloot, P.H. (2007). What is the value of entrepreneurship? A review of recent. Small Bus Econ, 351-382.

Weiss, T.G. (2015). Local understandings of the entrepreneur and entrepreneurship: A phenomenological case study from the southern highlands of Tanzania. University of Minnesota. Ann Arbor: ProQuest Dissertations Publishing.

West African Vocational Schools. (2015). The Difference Happens Here. Retrieved April 23, 2015, from West African Vocational Schools: http://wavschools.org/ about-us. 
Youth Entrepreneurship Facility. (2015). The YEF Approach. Retrieved April 10, 2015, from http://yefafrica.org/about-us/our-approach/. 


\section{Bibliographical notes}

Sharmila Sandirasegarane received her undergraduate degree with honors in Biobehavioral Health from the Pennsylvania State University, with minors in Global Health and Spanish. She is currently pursuing a medical degree at the Medical College of Georgia.

Staci Sutermaster is a recent B.S. with honors in Bioengineering from the Pennsylvania State University. She has acted as a co-manager of the One Heart Source Health Volunteer Program, a non-profit organization based in South Africa. She is currently planning to pursue a Master's degree in Public Health.

Alyssa Gill is a Fundraising \& Strategic Partnership Associate at the National Academy of Advanced Teacher Education (NAATE). She holds a B.A. in Political Science from the Pennsylvania State University.

Jennifer Volz graduated from the Pennsylvania State University with a B.A. in International Politics with three minors: Innovation \& Entrepreneurship, Italian, and Energy Business \& Finance. She is an analyst in the Finance division of Goldman Sachs.

Khanjan Mehta is the Founding Director of the Humanitarian Engineering and Social Entrepreneurship (HESE) Program. He is an Assistant Professor in Engineering Design with research interests that encompass affordable design; systems thinking; social entrepreneurship pedagogy; agricultural technologies and food value chains (FVCs); global health and telemedicine systems; cellphones, social networks and trust; indigenous knowledge systems; development ethics and grassroots diplomacy; women in engineering and entrepreneurship; and informal lending systems for micro-enterprises. 